\title{
Toward Epistemic Justice: A Critically Reflexive Examination of 'Sanism' and Implications for Knowledge Generation
}

\author{
STEPHANIE LEBLANC \\ Western University, Canada \\ ELIZABETH ANNE KINSELLA \\ Western University, Canada
}

\begin{abstract}
The dominance of medicalized "psy" discourses in the West has marginalized alternative perspectives and analyses of madness, resulting in the underinclusion (or exclusion) from mainstream discourse of the firsthand experiences and perspectives of those who identify as Mad. We argue that this marginalization of firsthand knowledge(s) demands closer critical scrutiny, particularly through the use of critical reflexivity. This paper draws on Fricker's concept of epistemic injustice, whereby a person is wronged in his or her capacity as a knower, as a useful framework for interrogating the subjugation of Mad knowledge(s). Also examined is the problem of sanism, a deeply embedded system of discrimination and oppression, as an underlying component of epistemic injustice. Sanism assumes a pathological view of madness, which can be attributed to what Rimke has termed psychocentrism: the notion that pathologies are rooted in the mind and/or body of the individual, rather than the product of social structures, relations, and problems. The paper examines how sanism marginalizes the knowledge(s) of Mad persons and contributes to epistemic injustice, and considers possibilities for advancing social justice using Mad epistemological perspectives.
\end{abstract}

KEYWORDS Mad; Mad studies; sanism; epistemic injustice; critical reflexivity; psychocentrism

\section{Introduction}

Madness as a phenomenon has existed throughout the course of human history, but it was not until the $18^{\text {th }}$ century that the organized field of psychiatry materialized (Foucault, 1988; Hornstein, 2002; Porter, 2002; Scull, 1989). In accordance with the growing dominance of medicalization, the 
concept of madness was eventually replaced by what is presently referred to as mental illness (Foucault, 1988; LeFrancois, Menzies \& Reaume, 2013; Rimke, 2003; Rimke \& Hunt, 2002; Wolframe, 2013b). Despite its displacement from modern mental health discourse, we use the term Mad to describe all persons who self-identify as such, or who have otherwise been deemed mentally ill or in need of psychiatric services (Poole et al., 2012; Wolframe, 2013b). Contemporary uses of this term may be familiar to those acquainted with critical scholarship on madness, however for many readers this may be new territory. For this reason, we preface this work with a brief discussion of the language and terms used throughout our analysis (Wolframe, 2013b).

The term Mad, when used in politicized and empowering discourses, is perhaps most strongly associated with the Mad movement, which materialized in the 1960s and 1970s in protest of the mistreatment and involuntary confinement (or "imprisonment") of those deemed mentally ill (Burstow, LeFrancois, \& Diamond, 2014; Chamberlin, 1990; Poole et al., 2012; Porter, 2002; Price, 2011; Scull, 1989; Wolframe, 2013b). Many of those taking part in the movement embraced the term Mad and chose to reclaim it as a politicized form of self-identification, much like the term queer has been reclaimed within the context of the LGBTQ2S movement (Burstow et al., 2014; Poole et al., 2012; Price, 2011; Reid, 2008; Rimke \& Brock, 2012).

Today, an increasing array of signifiers exist for representing the experiences of those living with mental and emotional diversity or distress, including, but certainly not limited to, ex-patient, mentally ill, consumer, psychiatric survivor, crazy, Mad, lunatic, neuro-diverse, disabled or deviant. Of these terms, we have purposely chosen to employ the term Mad, not only in attempt to reflect the multiple social constructions of mental diversity to date, but also to emphasize the politics of resistance to psy discourses (Price, 2011; Wolframe, 2013b). Psy discourses are taken as problematic, particularly when alternative perspectives - especially those held by Mad people - are subjugated (Hornstein, 2002; LeFrancois et al., 2013).

Mad people continue to contend with the suppression and dismissal of their knowledge, experiences, and perspectives, as revealed in the frequent absence or discrediting of Mad discourses in academic contexts, media portrayals, healthcare practices, research, policy, and everyday conversation (Fabris, 2011, Reaume, 2006; Russo \& Beresford, 2015; Wolframe, 2013a). A broad aim of Mad activists and scholars has been to balance the disproportionate emphasis on "official" knowledge with that of those experiencing madness firsthand (Chamberlin, 1990; Costa et al., 2012; Russo \& Beresford, 2015). The subjugation of Mad persons' experiences raises questions concerning power and knowledge, in particular, what constitutes valid knowledge(s), who are the legitimate knowers, and whose knowledge should count? (Fricker, 2007; Harding, 1991). The under-inclusion (or exclusion) of the perspectives of Mad people from academic, legal, clinical, and everyday 
discourses demands closer critical analysis.

This paper draws on Fricker's (2007) concept of epistemic injustice, as it provides a useful framework for analyzing and challenging the subjugation of Mad knowledge(s), particularly for those who view the political and epistemological struggles championed by the Mad movement as inseparable (Lewis, 2006; Russo \& Beresford, 2015). We have chosen to foreground this concept as we agree that the marginalization of Mad persons' experiences and resultant knowledges constitutes a form of epistemic injustice, and may be seen as an infringement on (Mad) persons' basic human rights (Fricker, 2007; Medina, 2012; Shotter, 1981). We argue that a failure to recognize the epistemic value of the perspectives of those living with madness is so entrenched in Western social practices and discourses (Rimke \& Brock, 2012) that epistemic injustice is often perpetuated without consideration of potential social harm (Fricker, 2007; Perlin, 2003).

This paper provides an overview of sanism, a deeply embedded form of discrimination and oppression affecting those who experience madness, and argues it is a system of thought underpinning the practice of epistemic injustice (Fabris, 2011; Fricker, 2007; Perlin, 2000, 2003; Russo \& Beresford, 2015; Spandler \& Carlton, 2009). This is reflected in what Rimke has termed psychocentrism, wherein pathologies are taken to be rooted in the mind and/or body of the individual, rather than the product of social relations, structures and problems (Rimke, 2003, 2010, 2011). In this paper we consider how the material and conceptual outcomes of sanism and psychocentrism marginalize the knowledge(s) of Mad persons. We further show that such marginalization constitutes a form of epistemic injustice, and argue that engagement with Mad epistemological perspectives is a matter of social justice.

\section{Epistemic Injustice and the Mad Community}

Fricker (2007, p. 1) introduces the concept of epistemic injustice as an injustice concerning "our most basic everyday practices: conveying knowledge to others by telling them, and making sense of our own social experiences," which occurs when a person is insulted or wronged in their capacity as knower. If it is our ability to know that makes us distinctively human, as has been suggested, it is no wonder that the "powerful" have historically undermined, insulted, or otherwise wronged the "powerless" in this capacity, as a means for denouncing their humanity (Fabris, 2011; Fricker, 2007; Medina, 2012; Price, 2011). Epistemic injustice is inextricably linked to social injustices, according to Medina (2012, p. 27), who suggests that "inequality is the enemy of knowledge," impairing our ability to know and to gain knowledge from others. Social injustice breeds epistemic injustice by weakening epistemic relations between marginalized social groups unfairly depicted as intellectually inferior and lacking credibility - and their 
epistemically privileged counterparts (Medina, 2012).

Epistemic injustice is comprised of two fundamental discriminatory forms: testimonial injustice and hermeneutical injustice (Fricker, 2007, 2010). Testimonial injustice occurs when a speaker is undermined in their capacity as a giver of knowledge, owing to an identity prejudice held by the hearer, impacting the hearer's judgement of the speaker's credibility (Fricker, 2007). Alternatively, hermeneutical injustice occurs when groups of people are wronged in their capacities as subjects of social understanding through structural prejudices which impact the production of (and access to) interpretive resources needed to make sense of their social experiences (Fricker, 2007; Medina, 2012). Although Fricker's terminology is seldom used among Mad scholars and activists, the experience of testimonial injustice is all too familiar, and is an important concept to consider as it describes a serious threat to the citizenship and humanity of Mad persons (Callard, 2014; Carel \& Kidd, 2014; Russo \& Beresford, 2015; Thachuk, 2011). The Mad community has focused even less attention on the notion of hermeneutical injustice, which perhaps suggests that the detection of hermeneutical injustice is more difficult (Fricker, 2007; Medina, 2012).

\section{Sanism: The Hidden Prejudice}

We argue that sanism, a system of thought deeply embedded in Western culture, contributes to the epistemic injustice experienced by Mad people (Fabris, 2011; Fricker, 2007; Mills, 2014; Spandler \& Carlton, 2009). Sanism involves the systematic subjugation and oppression of people who have received "mental health" diagnoses, or who are otherwise perceived to be "mentally ill" (Perlin, 1992, 2003; Poole et al., 2012). The term sanism was coined in the 1960s by activist lawyer, Mortin Birnbaum in conversation with prominent feminist lawyer, Florynce Kennedy (Birnbaum, 2010; Fabris, 2011). Michael Perlin, an activist and disability rights lawyer, later popularized the concept (Burstow et al., 2013; Fabris, 2011; Perlin, 2000). The large majority of literature on sanism is comprised of Perlin's writings and his collaborations with others, developed from nearly 30 years of personal observation (Fabris, 2011; Wiliams, 2013). Perlin focused on unfairness and inequalities in the legal system, but his analysis has applicability to many aspects of structural stigma, prejudice and discrimination (Williams, 2014).

Perlin (2003, p. 536) describes sanism as "an irrational prejudice of the same quality and character of other irrational prejudices that cause (and are reflected in) prevailing social attitudes of racism, sexism, homophobia, and ethnic bigotry," and every other "ism" society no longer tolerates. Sanism may take the form of blatant discrimination and various forms of stigma, however, it is also commonly expressed in a multitude of microaggressions, which consist of "multiple, small, insults and indignities" (Kalinowski \& 
Risser, 2005, as cited in Poole et al., 2012, p. 21; Burstow et al., 2013; Chamberlin, 1990; Goffman, 1963). Sanism is arguably one of the last socially accepted, government-sanctioned forms of systemic discrimination against a large social group (Jones \& Brown, 2013). Although sanism is as troubling as other forms of discrimination, it is especially insidious as it remains largely invisible, and is self-perpetuating, socially acceptable, and practiced regularly (Perlin, 1992, 2003; Poole et al., 2012; Wolframe, 2013b).

\section{Sanism and Psychocentrism: The Pathologizing of Individuals}

Sanism is conceptually dependant on, and reinforces the notion that Mad persons are fundamentally different from their "sane" counterparts (Perlin, 2000; 2003; Poole et al., 2012). Such a dichotomy aligns with what Rimke has termed psychocentrism: the view of human problems as pathologies rooted in the mind and/or body of the 'pathological individual', rather than the product of social problems (Rimke, 2003, 2010, 2011). Many contend that this "normal" is a mythical standard and that being labelled as mentally ill can occur as a result of performing, or being at risk of performing, socially unacceptable behaviours (Fabris, 2011; Rimke, 2011; Williams, 2014). The establishment of socially accepted and scientifically constructed norms has afforded psychiatry the authority to make inferences about the epistemic trustworthiness, credibility, or intellect of persons, dependant on their positioning in relation to such conceptions of normal (Morrow \& Weisser, 2012; Rimke, 2003, 2010).

\section{Testimonial Injustice}

Communicating Mad knowledge(s) through stories or testimonies has been foundational to the Mad community as a means of resisting psychiatric oppression and dehumanization (Costa et al., 2012). Members of the Mad community have protested that their perspectives are representative of "real" knowledge, only to have the legitimacy of their accounts questioned or dismissed altogether by virtue of their being Mad (Costa et al., 2012; Hornstein, 2002). As psychiatric survivor and activist Erick Fabris (2011, p. $31)$ writes, "we are not even credited with having experience; we are thought to have lost our minds, to be unreasonably emotional, possibly at the worst of times, a kind of philosophical exemplar of inaccessible life." The discrediting of Mad persons in their capacity as legitimate knowers represents what Fricker (2007) refers to as testimonial injustice. We argue that in this context, testimonial injustice occurs as a result of negative identity prejudice stemming from sanist thinking, which tacitly distorts judgments of Mad people's credibility as speakers (Goffman, 1963; Medina, 2012; Perlin, 2000).

Negative identity prejudice finds its way into discursive settings through a 
hearer's use of stereotypes, which he or she engages with as heuristic devices in order to weigh judgments of credibility (Fricker, 2007). Although stereotypes "oil the wheels of testimonial exchange," when underscored by negative identity prejudice, these can become troublesome for the speaker (Fricker, 2007, p. 32; 2010). This amalgam is referred to as negative identityprejudicial stereotype, which Fricker (2007, p. 35) defines as a "widely held disparaging association between a social group and one or more attributes, where this association embodies a generalization that displays some resistance to counter-evidence." When prejudicial stereotypes distort the credibility judgments of the hearer, an epistemic harm is inflicted, whereby knowledge that may have otherwise been recognized by the hearer is lost (Fricker, 2007).

In cases of testimonial injustice driven by prejudicial stereotypes that discredit the humanity of a speaker (i.e., the widespread stereotype that Mad people are incapable of rational thought), the harm being done to the speaker should be understood as more than simply symbolic (Fricker, 2007). Denigrating sanist stereotypes are based on, and reinforce, deep-seated social assumptions that mad persons are unable to exercise their full citizenship, and are therefore incapable of fully participating as knowers (Fabris, 2011; Fricker, 2007; Perlin, 2003; Williams, 2014). As such, the subjugation of Mad persons' knowledge, perpetuated each time a speaker is prevented from contributing knowledge to the public domain, becomes both justified and necessary (Williams, 2014). Mad scholarship is replete with examples of testimonial injustice, although they are not often acknowledged or recognized as such (Liegghio, 2013; Fabris, 2011; Saks, 2007; Thachuk, 2011; Williams, 2014; Wolframe, 2013a).

Perlin has written extensively about sanist stereotypes that cultivate irrational fears, ignorance, and so-called "common-sense" beliefs, which tend to inform how many people in society perceive, understand, and treat Mad persons (Fabris, 2011; Perlin 2003, 2006, 2013; Williams, 2014). Indeed, the credibility of Mad persons' knowledge is frequently judged through the hearer's lens of sanist prejudice (Fricker, 2007). Sanist stereotyping fosters a negative perception of Mad persons as delusional, emotionally unstable, unpredictable, untruthful, untrustworthy, lacking all capacity for "rational" thought, and invariably dangerous to oneself or others (Fabris, 2011; Perlin, 2000, 2003, 2006, 2013; Williams, 2014).

Perhaps the most pervasive sanist stereotype is the misconception that violence to oneself or others is a hallmark of madness (Wolframe, 2013a). Cultural assumptions surrounding the risk of violence often take precedence over the expressed perspectives of Mad persons, justifying the social control of Mad persons against their will through forced institutionalization or mandated psychiatric treatment (Fabris, 2011; Wolframe, 2013a). Maria Liegghio (2013) shares a moving narrative of her mother's end-of-life care which was tainted by her mother's psychiatric history and diagnosis of bipolar disorder - and of the consequent injustices to her capacity as a 
knower. Liegghio (2013) uses the term epistemic violence to describe the injustices experienced by her mother, and by herself, as the daughter of a Mad woman. Liegghio writes:

I am so angry! Today on this cold, Canadian winter day I am accompanying my mother, dying of cancer, living with physical pain, and struggling with mental confusion to the palliative care unit at the hospital after spending six months caring for her at home. All her in-home nursing and personal care support has been withdrawn and we have no other choice but to consider a hospitalization against my mother's wishes. And why - because someone in their position as helping authority decided she was a risk of harm to the visiting staff because of her history of 'mental illness.' [...] What risk of harm could this woman, too physically withered and weak to sit up, possibly pose to herself or others? [...] Is this really just a misunderstanding about a failing liver versus a mental illness? How is it possible that the knowledge of her impending death no longer exists and instead, the knowledge of 'mental illness' and all the prejudices associated with it have taken over and are used to justify such action, as to deny the necessary services and to deny the wishes of a dying woman? (Liegghio, 2013, pp. 122-123)

Liegghio (2013) explains that in her mother's 20-year history of living with the diagnosis of bipolar disorder she never harmed or threatened to harm herself or others. In accordance with sanist beliefs, however, Liegghio's mother was constructed as dangerous, and as a result, was undermined in her capacity as a legitimate knower.

Testimonial injustices also routinely occur in healthcare contexts when Mad persons' health concerns - even those entirely distinct from their psychiatric histories - are dismissed (Hinshaw, 2007; Rimke, 2003; Thachuk, 2011). Take for example, the report of a 38-year-old Mad woman in her dealings with the healthcare system:

Speaking to the tainting effects that her psychiatric history has had on her interactions with health-care providers, one woman states, 'I went to my GP with a breast lump ... [ [he] sent a referral letter stating 'over-anxious patient, had nervous breakdown at age 17' (20 years ago). Consequently I was greeted by the specialist with 'well, you're a bit of a worrier, aren't you?' Every physical illness I have had for the last 20 years has first been dismissed as anxiety, depression or stress. (Thachuk, 2011, p. 155)

Similarly, legal scholar and mental health-policy advocate, Elyn Saks (2007), who has for decades been diagnosed with chronic schizophrenia, writes of what might be characterized as testimonial injustice. In her memoir, The Center Cannot Hold (2007), she writes of seeking medical care for what was eventually determined to be a subarachnoid brain hemorrhage:

Quickly, they bundled me into the car and took me to the emergency room. Where a completely predictable disaster happened: the ER discovered I had a psychiatric history. And that was the end of any further diagnostic work. Stigma against mental illness is a scourge with many faces, and the medical community wears a 
number of those faces. A psychiatric patient at a program where Steve once worked went for weeks with a broken back; none of the medical people the patient saw took the man's pain seriously - he was a mental patient. So once the ER learned I had a mental illness and was on antipsychotic medication, the diagnosis was written in stone: I was 'just' having an episode. [...] The ER sent me away. (Saks, 2007, pp. 232-233)

With respect to navigating this sort of epistemic dilemma, Otto Wahl has suggested that, "the only way to have symptoms accepted as honest and accurate reports is to be dishonest about psychiatric history" (Wahl, 1999, cited in Thachuk, 2011, p. 155). Indeed, in order to be perceived as legitimate knowers, many Mad persons opt to conceal their psychiatric histories when speaking about their physical health concerns. As Thachuk (2011, p. 155) observes, "Ironically, one had best lie in order to avoid being perceived as a liar!"

\section{Pre-Emptive Silencing and Epistemic Objectification}

Discrediting expressed knowledge(s) in the midst of conversation is not the only way that testimonial injustices can occur. Fricker (2007) and Medina (2012) discuss two additional forms of testimonial injustice. The first of these is pre-emptive testimonial injustice or silencing, enacted through exclusion from participation in communicative exchange, where knowledge, judgments and opinions of marginalized groups are simply not solicited. It is important to clarify that this form of epistemic injustice is highly context dependent, and that our argument is largely limited to the constrained participation of Mad persons in the generation of (accepted) knowledge surrounding madness (Fricker, 2007; Medina, 2012). Within this particular context, the pre-emptive silencing of Mad persons can be attributed to the dominance of the 'psy' disciplines' widespread social acceptance of 'psy' knowledges and discourse as the "official" version of the truth.

The second of these forms of testimonial injustice, epistemic objectificiation, "allows" participation in communication for the purpose of knowledge-production and transmission; however, it relegates persons from the role of active epistemic agent (or subject) to that of passive object, to be studied, observed, and in many cases, exploited (Ficker, 2007, p. 132). In other words, it shifts the speaker's epistemic status from informant to source of information. We see evidence of this particular injustice in the production of knowledge surrounding mental health or madness, which consists primarily of work produced about, rather than by, Mad persons (Jones \& Brown, 2013; Russo \& Beresford, 2015).

According to Medina (2012), this too is a context-dependent form of injustice, for it is not inherently "wrong" to be regarded as object in epistemic interactions, as long as speakers are not solely regarded as such, and are also treated as subjects of knowledge within the same context. Moreover, not all 
objectifying or silencing is avoided when persons are treated as informants (Medina, 2012). Informants may still be undermined in their capacities as knowers and constrained or minimized as givers of knowledge "at the service of the inquirer's epistemic agency (her questions, her assessments, her interpretations)" (Medina, 2012, p. 92). As such, epistemic objectification may occur even when there is active participation in knowledge production.

Costa et al. (2012) have studied what they refer to as "patient porn" or "disability tourism," involving the personal narratives of Mad persons being co-opted by psy organizations to further their own interests, rather than to support Mad persons as agents of change. Patient porn is exemplified by mental health organizations' solicitation and subsequent sanitization or distortion of Mad persons' narratives about their "fall into and subsequent recovery from mental illness" owing to their participation within that organization (Costa et al., 2012, p. 86). This form of objectification is particularly insidious as it occurs under the guise of welcoming or embracing Mad persons' knowledge (as informants), yet the accounts are sanitized in a way that makes Mad knowledge largely invisible. Mad activists' resistance against epistemic objectification was demonstrated at a June 2011 Toronto event titled "Recovering Our Stories," using the slogan "Hands Off Our Stories" (Costa et al., 2012, p. 92). The goal was to "interrupt the proliferation of this popular type of storytelling within the mental health sector - judging it to be not just problematic but 'pornographic'," hoping that this might inspire others to instead, "use [their] stories to change the world" (Costa et al., 2012, p. 86, 92).

\section{Hermeneutical Injustice}

Thus far, we have explored the multiple facets of Fricker's testimonial injustice, as a wrong done to a person as a giver of knowledge, whether it be through dismissal and discrediting, pre-emptive silencing, or the objectification of shared Mad knowledge(s). Closely related to testimonial injustice is hermeneutical injustice. Hermeneutical injustice relates to hermeneutics, or the art of interpretation, which affects peoples' ability to express themselves or to be understood (Kinsella, 2006; Medina, 2012). Through hermeneutical injustice, "some significant area of one's social experience [is] obscured from collective understanding," owing to the presence of wrongful interpretive obstacles (Fricker, 2007, p.155). According to Medina (2012) it is through testimonial interaction that hermeneutical injustices occur (and are maintained): "those who are struggling to make sense are persistently not heard and their inchoate attempts at generating new meanings are blocked or unanswered" (Medina, 2012, p. 96). Hermeneutical injustices are revealed in the lack of opportunities for Mad persons to participate in the generation of interpretive resources for making sense of madness. As a distinct social group, Mad persons are often unable to make 
intelligible the nature of the harms they experience, owing to a lack of available hermeneutical resources for doing so (Fricker, 2007).

Fricker (2007) asserts that collective forms of social understandings are reflective of the perspectives of various social groups, whereby unequal power relations have the potential to skew shared hermeneutical (interpretive) resources. Psychiatrized conceptions of madness - or mental illness - have dominated the West since the $18^{\text {th }}$ century, where the growth of the "psychiatric empire" (Beresford, 2013, p.ix) continues to develop on a global scale (LeFrancois et al., 2013). Oppressed social groups may be hermeneutically marginalized to the extent that they must interpret their social experiences, "through a glass, darkly, with at best ill fitting meanings to draw on in the effort to render them intelligible" to others, and in some cases, to themselves (Fricker, 2007, p. 148; Medina, 2012). Members of the Mad community may be particularly vulnerable to this form of epistemic injustice due to the elusive nature of madness (which makes it difficult to understand and communicate), resulting in their marginalization as contributors to the collective hermeneutical resource (Carel, 2013; Carel \& Kidd, 2014).

The usefulness of the concept of hermeneutical injustice can be seen in Wolframe's (2013a) account of her experience of sanist oppression and sane privilege amid a culture in which the concept of sanism is not yet widely recognized. Upon her discovery of the concept of sanism, Wolframe was able to find new interpretive resources to communicate her experiences:

I did not recognize for some time the fact that people who had never been labeled mentally ill - as I had been - and who were thus sane by default, had access to privileges that I did not. I was aware of the discrimination I had faced as a "mentally ill" person, but I accepted that oppression. I believed, at the time, that I was sick, and I believed that this sickness caused me to hurt myself and others. Should I not then, I reasoned, be restrained by the straightjacket of unequal treatment? It was only later when I came to reject the medical model of madness that I questioned my own internalization of an oppression I came to know as saneism [sic]. Though I began to think through the idea of saneism at the same time as I got free of psychiatry, in 2005, I only started to recognize sane privilege recently, as I have increasingly gained that privilege myself... Since people have not always treated me as though I am reasonable, trustworthy, safe to be around, and capable of taking care of and making decisions for myself, because they knew I had been diagnosed as, or they perceived me to be mentally ill, I very much notice it now that they do treat me as though I am all of these things most of the time. Now that I am experiencing it, sane privilege has become obvious to me. It is not necessarily so obvious to those who have never lost that privilege. (Wolframe, 2013a, paragraph 6-7)

\section{Hermeneutical Injustice Through Imposed Silence}

According to Foucault (1980), those in positions of power act in ways that 
serve to legitimize their own knowledge, while simultaneously undermining other knowledge that may challenge their dominant ways of knowing (Rimke, 2003; Geekie, 2004). Mad persons have been represented as possessing a "lack of insight" should they not interpret their experiences according to dominant psy discourses (Amador \& Kronengold, 1998; Geekie, 2004; Kirmayer \& Corin, 1998; Rimke \& Hunt, 2002). This portrayal serves as a powerful instrument for the hermeneutical marginalization and discrediting of Mad persons (Fricker, 2007; Geekie, 2004). If a lack of insight is to understand one's experiences in ways alternative to the dominant hermeneutical resources put forth by psy disciplines, then all persons deemed to have insight must invariably espouse dominant hermeneutical resources. This is supported by a dominant collective belief that if it were not for Mad persons' insight-impairing "illness" they would embrace these dominant interpretations, and as such, should be "grateful for the imposition of laws and judicial decision-making that ensure they are protected, controlled, and treated" (Williams, 2014, p. 451). Williams points out that despite a growing consciousness around injustices affecting other marginalized populations, sanist belief systems continue to provide justification for the unjust treatment of Mad persons:

No-one believes that a suffragette would have been grateful for being imprisoned and gastric fed; or an African American would have been grateful for being enslaved; or a cancer patient who is refusing treatment will be grateful for being locked up until they agree, or are compelled, to undergo chemotherapy. (Williams, 2014, p. 451)

Despite the presence of Mad persons' perceptive, nuanced and welldeveloped theories surrounding the experience of madness, the collective hermeneutical resource for interpreting the social experience of madness is heavily saturated by psy discourses, such that alternative epistemological perspectives on madness are regularly subjugated and dismissed (Geekie, 2004; LeFrancois et al., 2013; Williams, 2014; Wolframe, 2013b).

\section{Illuminating Injustices in the Midst of a Hermeneutical Lacuna}

The marginalization of Mad persons' knowledges may be due to a hermeneutical lacuna, resulting in a paucity of language or concepts available to discuss experiences of injustice (Carel \& Kidd, 2014; Geekie, 2004; Fricker, 2007). Some persons may find that their experiences of madness, or its related injustices, cannot be communicated in "any direct, propositional manner, and so are only shareable with persons with whom one shares a standpoint or a sense of solidarity" (Carel \& Kidd, 2014, p. 530; Geekie, 2004). Fricker (2007, p. 160) described hermeneutical lacunae as "absences of proper interpretations, blanks where there should be a name for an experience which it is in the interests of the subject to be able to render 
communicatively intelligible." For Mad persons there may well be an extant hermeneutical lacuna hindering the articulation of the experience of sanist aggressions, both systemic and in the form of microaggressions (Poole et al., 2012; Williams, 2014; Wolframe, 2013b). The danger of hermeneutical lacunae is that even those enacting sanist aggressions are often unaware of the implications of their unjust words or actions (Wiliams, 2014). In this way, both the harasser and harassee are cognitively handicapped in their ability to make sense of the injustices taking place (Fricker, 2007). However, hermeneutical lacunae do not affect each party equally (Medina, 2012). The harassee is significantly disadvantaged by this gap in hermeneutical resources, which render her less able to make sense of, and to communicate, ill treatment, and thus perhaps less likely to protest the injustice altogether (Fricker, 2007).

Increasing public awareness of racism, sexism, ageism and homophobia as social problems has decreased hermeneutical lacunae in these domains, and contributed to making such systems socially unacceptable (Byrne, 2010; Perlin, 2003). Conversely, the large majority of Mad persons still lack adequate hermeneutic resources for describing the prejudice and discrimination against them (Byrne, 2010; Williams, 2014). Medina (2012) cautions, however, against tying too closely hermeneutical capacities and the repertoire of readily available articulations for describing injustices, as Mad persons' have been expressing their experiences of injustice and oppression since long before coined concepts and terminology emerged. With the proliferation of ex-patient movements in the 1960s and 1970s came a greater realization of the existence of negative prejudices attached to Mad persons (Williams, 2014). This spurred initial attempts to establish definitive language for resisting judgements of Mad persons as invariably incompetent, unpredictable, irrational and violent (Rimke, 2010; Williams, 2014). Judi Chamberlin (1990), one of the early leaders of the ex-patient movement, coined the term mentalism (also variously referred to as sane chauvinism, psychophobia and now, sanism), to describe prejudices directed at persons with psychiatric diagnoses or who were otherwise considered Mad (Byrne, 2000; Williams, 2014).

Williams (2014) argues that a crucial first step in propagating the idea of sanism as a social justice issue for Mad persons is universal acceptance of the term. To this end, it is appropriate to briefly discuss the conceptual differences between sanism and mental health stigma as distinct concepts, to deter their interchangeable use in the future. Stigma can be viewed as the outward manifestations of "an overarching oppression constructed on a foundation of sanist beliefs, attitudes and practices" (Williams, 2014, p. 13). According to Poole et al. (2012, p. 21) a focus on mental health stigma is too limiting, in that "it minimizes the jagged reality of widespread rights abuse and oppression (or sanism) experienced by individuals with such mental health histories." Sanism, unlike stigma, also has the expressed "aim to unsettle assumptions about rationality, normality, and madness" (Morrow \& 
Weisser, 2012, p. 29). As such, it is an important concept in matters relating to the rights and wellbeing of Mad persons, as it "points to the social, cultural, and material dividing of 'mentally ill' bodies from 'healthy' reasoned ones, while questioning the idea that such categories are easily established and maintained" (Wolframe, 2013b, pp. 9-10).

Following Poole et al. (2012), we argue that the term sanism serves the important cognitive and discursive function of shining light in the hermeneutical darkness that prevents Mad persons' from fully understanding the injustices experienced in the name of healthcare, and public and personal safety (Fricker, 2007). Perlin's adoption of the concept of sanism (drawing on Birnbaum's writings) for making sense of his observations of the legal system's mistreatment of Mad persons, is evidence of a hermeneutical triumph (Williams, 2014). Wolframe too found consolation in discovering the concept:

At the age of 16 , I was assigned to a new psychiatrist and given a new 'adult' diagnosis. I was treated for this supposed disease - on both an inpatient and outpatient basis, using a cocktail of different drugs - for approximately six years. Although I questioned my diagnosis before I got clear of psychiatry in my early 20 's, it was not until I became a graduate student that I first read about the Mad movement and finally had words to describe my experiences other than those used by psychiatry. I only wish I had heard about the Mad movement earlier, and that I could have, as an undergraduate student in English and Women's Studies, talked about sanism along-side racism, heterosexism, cissexism, ageism, classism and all those other isms (Wolframe, 2013a, pp. 1-2).

Fricker (2007, p. 148) reminds us that "from a hermeneutical position of relative comfort, one can forget quite how astonishing and life-changing a cognitive achievement of this sort can be." As a Mad-identified scholar, the first author of this paper can certainly attest to the liberating potential of the concept of sanism from a place of hermeneutical marginalization and social injustice. Exposing the pervasiveness of sanism as a deeply damaging form of systemic oppression should, in theory, render the once invisible, visible, and by extension, the once acceptable, unacceptable (Williams, 2014). However, this exposure does not guarantee that Mad knowledge will not be marginalized by those dominating the collective hermeneutic resource, predominantly the psy disciplines (Fricker, 2007). The possibility for continued hermeneutical marginalization even in light of the exposure of sanism, may be supported by the insights of Fellows and Razack (1998), who suggest that when people cannot relate to a particular "manifestation of oppression," or are in some way privileged as a result of it, they may be more likely to discredit others' claims of injustice (as cited in Diamond, 2014, p. 200). 


\section{Critical Reflexivity and Epistemic Justice}

Within the past decade interest surrounding human rights and "mental illness" has grown considerably among academics, practitioners, activists, and self-advocates (Perlin, 2000, 2003, 2013; Williams, 2014). As a result, violations of persons' mental health rights are finally gaining recognition as violations of human rights (Perlin, 2013). This being said, many injustices directed at the Mad community have yet to be widely acknowledged (Fricker, 2007; Liegghio, 2013). Epistemic injustice, for example, has not been much appreciated as a profoundly damaging ethical wrong. According to Fricker (2007, p. 40), with such an appreciation "perhaps we [as a society] would be more ready to voice our resentments and argue them through to some sort of rectification; and perhaps a social shift would occur towards developing a better vocabulary and forum for airing and responding to such complaints." We have explored the ways in which sanist oppression has contributed to epistemic injustices in the Mad community, and we now wish to open a much needed conversation about possibilities for moving toward epistemic justice.

Williams (2014) suggests that society does not condone prejudice or discrimination being perpetrated against Mad persons; rather, it is simply unable to recognize such transgressions when they occur. He argues, however, that "it is essential that society becomes aware of their own assumptions about human behaviours, values, biases, preconceived notions, personal limitations, and that they try to actively understand the different world view of a person experiencing mental illness, without negative judgment" (Williams, 2014, pp. 451-452). We support Fricker's (2007) claim that acknowledging the role of negative identity and prejudicial stereotypes in shaping a hearer's credibility judgment can be a crucial epistemic resource for persons who are to become epistemically just hearers. We have sought to make Perlin's concept of sanism more visible, so that its power and pervasiveness might be better understood and appreciated (Williams, 2014). Given that "the social imagination can be a powerful positive force for social change" (Fricker, 2007, p. 40), we argue that reflexive awareness can be a means of moving toward epistemic justice for Mad persons, by altering understandings and beginning to correct identity-prejudiced belief systems. Indeed, we are suggesting that most of the work toward eradicating epistemic injustice needs to be achieved through the reflexive efforts of hearers (Fricker, 2007). Such hearers need not be what Medina (2012) refers to as hermeneutical heroes: extremely courageous listeners (and speakers) who disrupt epistemic trends, making room for new meanings and interpretive perspectives. Instead, creating awareness of the conditions that support both testimonial and hermeneutical justice demands reflexive awareness on the part of ordinary, but epistemically sensitive, listeners (Fricker, 2007).

Epistemic sensitivity requires engagement in self-criticism and openness to changing negative patterns of credibility judgment and interpretive habits, so that the unprejudiced perception of another human being might transcend 
deeply entrenched negative identity prejudices and stereotypes (Fricker, 2007). One must begin to assess not simply the likelihood that the speaker's utterance is true, but also the truthfulness of the hearer's interpretation (Fricker, 2007; Medina, 2012). In doing so, a hearer may begin to recognize that perhaps her understandings are embedded within power imbalances related to the production of given knowledges. While hearers cannot be expected to suddenly develop complete openness in this regard, it is important, as Medina (2012) reminds us, to be mindful of the wiggle-room that exists for modifying such problematic habits.

In addition to reflexive self awareness, critical reflexivity in a broader social sense may also be used as an approach to question taken-for-granted knowledge claims related to madness, and for recognizing the ways in which unequal power relations may contribute to the available resources for understanding Mad experiences (Kinsella \& Whiteford, 2009). Critical reflexivity, not to be confused with reflection, is defined by Kinsella and Whiteford (2009) in accordance with the work of social philosopher Barry Sandywell (1996), as "the act of interrogating interpretive systems that influence knowledge production," whereby the "sociality of the process of knowledge production" is acknowledged (Kinsella \& Whiteford, 2009, pp. 250-251). Critical reflexivity involves careful interrogation of the grounds upon which taken-for-granted, or normative, claims about knowledge are generated and accepted, along with the situated perspectives from which knowledge claims are produced (Harding, 1991; Kinsella \& Whiteford, 2009; Kinsella, 2012; McCorquodale \& Kinsella, 2015; Phelan, 2011; Sandywell, 1996).

A critically reflexive hearer attempts to become aware of how the "relation between [her] social identity and that of the speaker is impacting on the intelligibility to her of what [the speaker] is saying and how she is saying it" (Fricker, 2007, p. 169). In this way the hearer is aware that the speaker's relative unintelligibility to her is perhaps a function of "a collective hermeneutical impoverishment, and [she] can adjust or suspend [her] credibility judgment accordingly" (Ficker, 2007, p. 7). Furthermore, a critically reflexive hearer can acknowledge that while to her a speaker's testimony is seemingly unintelligible due to the speaker's hermeneutically disadvantaged position, to another hearer the speaker may be communicating manifestly important knowledge (Carel \& Kidd, 2014; Fricker, 2007). Hearers can move toward hermeneutical justice by seeking, including, listening, and being open to speakers' interpretations, and viewing these as important contributors to knowledge generation (Carel \& Kidd, 2014; Fricker, 2007).

Using an example provided by Carel and Kidd (2014) to consider what hermeneutical justice might look like, we can suppose that if confronted with a testimonial exchange whereby the speaker's interpretation seemed relatively unintelligible, the critically reflexive hearer might think to herself: 
Although I do not quite understand what you are attempting to communicate, I do not see it as a fault of yours, but mine. Even your best efforts to make yourself understood are failing, not because of their inarticulacy, but because I am unable to appreciate the sort of articulacy you are using, and this hermeneutical context does not provide me with those resources (Carel \& Kidd, 2014, p. 532).

Badwall (2016) cautions against the use of reflexivity that does not take into account the multiplicity of subject positions that shape identities or the colonial roots of taken-for-granted approaches to knowledge generation, such as the curriculum offered in professional schools or faculties (e.g., Social Work or Medicine). She argues that particular institutional and colonized sites may create conditions in which critical reflexivity does the opposite of its intentions, for example "when the issues that workers can or cannot discuss are determined by their organizations" (Badwall, 2016, p. 16) or are "contingent upon colonial continuities designed to govern the parameters of what can be reflected upon" (p. 17). While deeper engagement with this critique is beyond the scope of the present paper, it is important to acknowledge that sanism is inextricable from other forms of oppression (Poole \& Jivrav, 2015). As such, the problem of epistemic injustice should be explored further within the context of intersecting oppressions and prejudices, such as the racialization or gendering of Mad bodies.

\section{Engagement with Alternative Epistemological Perspectives}

Knowledge(s) that differ from dominant discourses and ideologies are too often deemed "alien" and dismissed or ignored. However, epistemic interactions oriented toward justice require us to make room for, and embrace, plural and diverse knowledge(s) (Kinsella \& Whiteford, 2009; Medina, 2012). In this sense, justice carries with it generative epistemic possibilities, as it is often alien knowledge that forces a radical questioning of taken-for-granted assumptions, and calls for a "rearticulation of epistemic norms" (Medina, 2012, p. 47). It would be limiting to make sense of madness according to psy discourses alone, in light of the multiplicity of meaning(s) to be made of such realities (Fricker, 2007). In order to broaden our epistemic considerations we must first begin to "regard everyone's self-narrative as central" (Fabris, 2011, p. 31).

Situated stories and firsthand accounts by members of the Mad community offer epistemic resources to which we must attend. According to Foucault (1980), simply giving voice to and hearing subjugated knowledge provides a means for challenging the hegemony of dominant discourses. This perspective is echoed by Fabris $(2011$, p. 34), who writes that "to contest force in psychiatric arrangements requires more than empathy or technique in the other's 'best interest,' and more than knowledge about us without us." In order to tap into the subjugated knowledge of Mad persons, Fabris offers an alternative way of knowing madness that is filled with epistemic possibility: 
Madness is sound, but not because we live in a mad world (there is nothing mad about it either). We have identity in 'mad' experience, in difference, not despite it. I would like to suggest that madness is not only excusable, interesting, or a version of rationality under pressure. Madness is an embodied way to know. It is intelligent, searching, and valuable. It is not regression, but a conscious reaching out, as is technical work, healing love, or creative feeling. Purpose is not impossible in 'madness,' but it is also not easily described in a non-normative relation to the world. (Fabris, 2011, pp. 31-32)

\section{Conclusion}

Throughout this paper we have examined Fricker's (2007) concept of epistemic injustice as it relates to the marginalization of Mad knowledge(s), linking the concept with that of sanism and psychocentrism. We have also engaged with the concept of critical reflexivity as a means to participate in the pursuit of epistemic justice. It is our hope that this work will serve as a foothold for those seeking to further explore epistemic justice(s) for Mad persons, and to engage in critical interrogation of the hegemony of sanism, psychocentrism and psy discourses.

Epistemic injustices in the Mad community "call for epistemic resistance," and the fight against epistemic injustices belongs to the entire collective social body (Medina, 2012, p. 3). Each of us has the ability, perhaps even responsibility, to use our epistemic resources toward challenging taken-forgranted ways of knowing madness (Fricker, 2007; Medina, 2012). We argue for a broadening of epistemological horizons, inclusive of Mad knowledges and welcoming of the Mad community's full epistemic participation.

\section{References}

Amador, X., \& Kronengold, H. (1998). The descriptions and meaning of insight in psychosis. In X. Amador \& A. David (Eds.), Insight and psychosis (pp. 15-32). Oxford: Oxford University Press.

Badwall, H. (2016). Critical reflexivity and moral regulation. Journal of Progressive Human Services, 27(1), 1-20.

Beresford, P. (2013). Foreward. In B. LeFrançois, R. Menzies, \& G. Reaume (Eds.), Mad matters: A critical reader in Canadian mad studies (pp. ix-xii). Toronto: Canadian Scholars Press.

Birnbaum, R. (2010). My father's advocacy for a right to treatment. Journal of the American Academy of Psychiatry and the Law Online, 38(1), 115-123.

Burstow, B., Daley, A., Davies, M., Diamond, S., Finkler, L.C., Gorman, R., . . Voronka, J. (2013). Glossary of terms. In B. LeFrancois, R. Menzies, \& G. Reaume (Eds.), Mad matters: A critical reader in Canadian mad studies (pp. 334-340). Toronto: Canadian Scholars Press.

Burstow, B., LeFrancois, B., \& Diamond, S. (Eds.). (2014). Psychiatry disrupted: Theorizing resistance and crafting the (r)evolution. Montreal \& Kingston: McGill-Queen's University Press.

Byrne, P. (2000). Stigma of mental illness and ways of diminishing it. Advances in Psychiatric 
Treatment, 6(1), 65-72.

Byrne, P. (2010). Challenging healthcare discrimination. Advances in Psychiatric Treatment, 16(1), 60-62.

Callard, F. (2014). Psychiatric diagnosis: The indispensability of ambivalence. Journal of Medical Ethics, 40(8), 526-530.

Carel, H. (2013). Bodily doubt. Journal of Consciousness Studies, 20(7-8), 178-197.

Carel, H., \& Kidd, I. J. (2014). Epistemic injustice in healthcare: A philosophial analysis. Medicine, Health Care and Philosophy, 17(4), 529-540.

Chamberlin, J. (1990). The ex-patients' movement: Where we've been and where we're going. The Journal of Mind and Behavior, 11(3), 323-336.

Costa, L., Voronka, J., Landry, D., Reid, J., McFarlane, B., Reville, D., \& Church, K. (2012). Recovering our stories: A small act of resistance. Studies in Social Justice, 6(1), 85-101.

Diamond, S. (2014). Feminist resistance against the medicalization of humanity: Integrating knowledge about psychiatric oppression and marginalized people. In B. Burstow, B. LeFrancois, \& S. Diamond (Eds.), Psychiatry disrupted: Theorizing resistance and crafting the (r)evolution (pp. 194-207). Montreal \& Kingston: McGill-Queen's University Press.

Fabris, E. (2011). Tranquil prisons: Chemical incarceration under community treatment orders. Toronto: University of Toronto Press.

Fellows, M. L., \& Razack, S. (1998). The race to innocence: Confronting hierarchical relations among women. Journal of Gender, Race and Justice, 1, 335.

Foucault, M. (1980). Power/knowledge: Selected interviews and other writings. NewYork: Pantheon.

Foucault, M. (1988). Madness and civilization: A history of insanity in the age of reason. (R. Howard, Trans.). New York: Vintage.

Fricker, M. (2007). Epistemic injustice: Power and the ethics of knowing. Oxford: Oxford University Press.

Fricker, M. (2010). Replies to Alcoff, Goldberg, and Hookway on epistemic injustice. Episteme, 7, 164-178.

Geekie, J. (2004). Listening to the voices we hear: Clients' understandings of psychotic experiences. In J. Read, L. R. Mosher, \& R. Bentall (Eds.), Models of madness: Psychological, social and biological approaches to schizophrenia (pp. 147-160). New York: Brunner-Routledge.

Goffman, E. (1963). Stigma: Notes on the management of spoiled identity. Englewood Cliffs, NJ: Prentice-Hall.

Harding, S. G. (1991). Whose science? whose knowledge?: Thinking from women's lives. Ithaca, NY: Cornell University Press.

Hinshaw, S. (2007). The mark of shame: Stigma of mental illness and an agenda for change. Toronto: Oxford University Press.

Hornstein, G. (2002). Narratives of madness, as told from within. Chronicle of Higher Education, $48,20$.

Jones, N. \& Brown, R. L. (2013). The absence of psychiatric C/S/X perspectives in academic discourse: Consequences and implications. Disability Studies Quarterly, 33(1). Retrieved from http://dsq-sds.org/article/view/3433/3198.

Kalinowski, C., \& Risser, P. (2005). Identifying and overcoming mentalism. InforMed Health Publishing \& Training. Retrieved from http://www.newmediaexplorer.org/sepp/Mentalism.pdf

Kinsella, E. A. (2012). Practitioner reflection and judgement as phronesis: A continuum of reflection and considerations for phronetic judgement. In E. A. Kinsella \& A. Pitman. (Eds.), Phronesis as professional knowledge: Practical wisdom in the professions (pp. 3552). Rotterdam: Sense Publishing.

Kinsella, E. A. (2006). Hermeneutics and critical hermeneutics: Exploring possibilities within the art of interpretation. Forum: Qualitative Social Research, 7(3), Art. 19 [49 paragraphs].

Kinsella, E. A. \& Whiteford, G. (2009). Knowledge generation and utilization: Toward epistemic reflexivity. Australian Occupational Therapy Journal, 56(4), 249-258. 
Kirmayer, L. and Corin, E. (1998). Inside knowledge: Cultural constructions of insight in psychosis. In X. Amador \& A. David (Eds.), Insight and Psychosis (pp. 193-220). Oxford: Oxford University Press.

LeFrancois, B., Menzies, R., \& Reaume, G. (Eds.). (2013). Mad matters: A critical reader in Canadian mad studies. Toronto: Canadian Scholars Press.

Lewis, B. (2006). A mad fight: Psychiatry and disability activism. In L. Davis (Ed.), The Disability Studies Reader (2 ${ }^{\text {nd }}$ Ed.), (pp. 339-354). New York: Routledge.

Liegghio, M. (2013). A denial of being: Psychiatrization as epistemic violence. In B. Lefrancois, R. Menzies, \& G. Reaume (Eds.), Mad matters: A critical reader in Canadian mad studies (pp. 122-129). Toronto: Canadian Scholars Press.

McCorquodale, L. \& Kinsella, E. A. (2015). Critical reflexivity in client-centred therapeutic relationships. Scandinavian Journal of Occupational Therapy, 22(4), 311-317.

Medina, J. (2012). The epistemology of resistance: Gender and racial oppression, epistemic injustice, and the social imagination. Oxford: Oxford University Press.

Mills, C. (2014). Sly normality: Between quiescence and revolt. In B. Burstow, B. LeFrancois, \& S. Diamond. (Eds.), Psychiatry disrupted: Theorizing resistance and crafting the (r)evolution (pp. 208-224). Montreal \& Kingston: McGill-Queen's University Press.

Morrow, M. \& Weisser, J. (2012). Towards a social justice framework of mental health recovery. Studies in Social Justice, 6(1), 27-43.

Perlin, M. (1992). On 'Sanism'. SMU Law Review, 46, 373-407.

Perlin, M. (2000). The hidden prejudice: Mental disability on trial. Washington, DC: American Psychological Press.

Perlin, M. (2003). You have discussed lepers and crooks: Sanism in clinical teaching. Clinical Law Review, 9, 683-729.

Perlin, M. (2006). International human rights and comparative mental disability law: The role of institutional psychiatry in the suppression of political dissent. Israel Law Review, 39(3), 7374.

Perlin, M. (2013). "There must be some way out of here": Why the convention on the right of persons with disabilities is potentially the best weapon in the fight against sanism. Psychiatry, Psychology, and Law, 20(3), 462-476.

Phelan, S. K. (2011). Constructions of disability: A call for critical reflexivity in occupational therapy. Canadian Journal of Occupational Therapy, 78, 164-172.

Poole, J. \& Jivrav, T. (2015). Mental health, mentalism, and sanism. International Encyclopedia of the Social \& Behavioural Sciences, 2(15), 200-203.

Poole, J., Jivraj, T., Arslanian, A., Bellows, K., Chiasson, S., Hakimy, H., . . Reid, J. (2012). Sanism, 'mental health', and social work/education: A review and call to action. Intersectionalities: A Global Journal of Social Work Analysis, Research, Polity, and Practice, 1, 20-36.

Porter, R. (2002). Madness: A brief history. Oxford: Oxford University Press.

Price, M. (2011). Mad at school: Rhetorics of mental disability and academic life. Ann Arbor, MI: University of Michigan Press.

Reaume, G. (2006). Mad people's history. Radical History Review, 94, 170.

Reid, J. (2008). Social work practice with the mad community: Presenting an alternative (Unpublished paper). Ryerson University, Toronto, Canada.

Rimke, H. (2000). Governing citizens through self-help discourses. Cultural Studies, 14(1), 6178.

Rimke, H. (2003). Constituting transgressive interiorities: $19^{\text {th }}$-century psychiatric readings of morally mad bodies. In A. Arturo (Ed.), Violence and the body: Race, gender and the State (pp. 403-28). Bloomington, Indiana: Indiana University Press.

Rimke, H. (2010). Consuming fears: Neo-liberal in/securities, cannibalization, and psychopolitics. In J. Shantz (Ed.), Racism and borders: Representation, repression, resistance (pp. 95-112). New York: Algora Publishing.

Rimke, H. (2011). The pathological approach to crime: Individually based theories. In K. Kramar (Ed.), Criminology: Critical Canadian perspectives (pp. 78-92). Toronto: Pearson Education Canada.

Rimke, H. \& Brock, D. (2012). The culture of therapy: Psychocentrism in everyday life. In D. 
Brock, R. Raby \& M. Thomas (Eds.), Power and everyday practices (pp. 182-202). Toronto: Nelson.

Rimke, H. \& Hunt. A. (2002). From sinners to degenerates: The medicalization of morality. History of the Human Sciences, 15(1), 59-88.

Russo, J. \& Beresford, P. (2015). Between exclusion and colonisation: Seeking a place for mad people's knowledge in academia. Disability and Society, 30(1), 153-157.

Saks, E. R. (2007). The centre cannot hold. New York: Hyperion Books.

Sandywell, B. (1996). Reflexivity and the crisis of western reason: Logological investigations (Vol. I). New York: Routledge.

Scull, A. T. (1989). Social order/mental disorder: Anglo-American psychiatry in historical perspective (Vol. 3). Oakland, CA: University of California Press.

Shotter, J. (1981). Vico, moral worlds, accountability and personhood. In P. Heelas, \& A. Lock (Eds.), Indigenous Psychologies of Self (pp. 266-284). London: Academic Press.

Spandler, H. \& Carlton, T. (2009). Psychosis and human rights: Conflicts in mental health policy and practice. Social Policy and Society, 8(2), 245-256.

Thachuk, A. K. (2011). Stigma and the politics of biomedical models of mental illness. International Journal of Feminist Approaches to Bioethics, 4(1), 140-163.

Wahl, O. F. (1999). Mental health consumers' experience of stigma. Schizophrenia Bulletin, 25(3), 467.

Williams, V. (2014). 'Sanism', a socially acceptable prejudice: Addressing the prejudice associated with mental illness in the legal system (Unpublished doctoral dissertation) University of Tasmania, Hobart.

Wolframe, P. M. (2013a). The madwoman in the academy, or, revealing the invisible straightjacket: Theorizing and teaching saneism and sane privilege. Disability Studies Quarterly, 33(1). Retrieved from http://dsq-sds.org/article/view/3425

Wolframe, P. M. (2013b). Reading through madness: Counter-psychiatric epistemologies and the biopolitics of (in) sanity in post-World War II Anglo-Atlantic women's writing (Unpublished doctoral thesis). McMaster University, Hamilton, ON. 